\title{
Повесть Гоголя «Вий» и метасюжет о Медее (Еврипид, Сенека, Ахматова)
}

\author{
СЕРГЕЙ ШУЛЬЦ \\ Sergei SHUL’TS, 3-я линия, д. 5, кв. 28, RU-344019 Ростов-на-Дону \\ E-mail: s_shulz@mail.ru
}

(Received: 27 May 2018; accepted: 6 September 2018)

\begin{abstract}
In the present paper, Gogol's story Vij is considered in the context of the metaplot about Medea (see Euripides and Seneca). The connection between the metaplot for Gogol and the Renaissance context is shown. For the sake of comparison, Akhmatova's version of the Medea myth is also involved.
\end{abstract}

Keywords: Gogol, Euripides, Seneca, Akhmatova, Medea, Renaissance

С учетом знаменитого «античного» колорита повести «Вий» сюжетную линию панночки допустимо истолковать в плане имплицитной отсылки в том числе к образу Медеи как «ведьмы»/ «волшебницы» в ее любовных перипетиях. В самом деле, в повести Гоголя актуализирован не только мотив магии / ведьмовства, но и мотив неких «любовных» аффектов панночки, причем соотнесенных с идеей сверхъестественного.

Образ панночки в качестве ведьмы имеет отношение также к образу колдуна из повести «Страшная месть», что приводит к дальнейшему повороту намеченной нами интерпретации. В «Мастерстве Гоголя» Андрей Белый дает толкование образа колдуна из «Страшной мести» в качестве фигуры, «тронутой Возрождением», сходной с Альбертом Великим или Генрихом из Орильяка. Для А. Белого «сомнительно, что „легенда“ о преступлениях колдуна не бред расстроенного воображения выродков сгнившего рода, реагирующих на Возрождение», а «знаки, писанные „не русскою и не польскою грамотою“, - предполагает исследователь, - писаны... по-французски, или по-немецки; черная вода - кофе; колдун - вегетарианец; он занимается астрономией и делает всякие опыты...» (БЕлый 1996: 80).

Согласно верному комментарию Л. А. Сугай, «подобная реабилитация неслыханного грешника придавала иные черты символическому сближению Колдуна и Гоголя, как личности, всем чужой, никем не понимаемой» (СугАй 2011: 423) - но и, добавим, раскрывала в самом Гоголе нечто «ренессансное». ${ }^{1}$

\footnotetext{
${ }^{1}$ Ренессансное начало отмечал в своей позднейшей статье о Гоголе и тем самым дезавуировал свои прежние противогоголевские инвективы В. В. Розанов (см. РозАнов 1995; ср. также Шульц 1994: 45-47).
} 
Оценка А. Белого так или иначе провоцирует попытку и фигуру панночки истолковать через «ренессансную» призму. В подобном ракурсе она предстает «индивидуалисткой», «своевольницей», носительницей «эстетизма» ведь, например, во время полета с Хомой она открывает бурсаку эстетическую красоту мироздания: «Он видел, как вместо месяца светило там какоето солнце; он слышал, как голубые колокольчики, наклоняя свои головки, звенели. Он видел, как из-за осоки выплывала русалка, мелькала спина и нога, выпуклая, упругая, вся созданная из блеска и трепета» и т. п. (Гоголь 2009: 422). А. Ф. Лосев в связи с Ренессансом говорил именно о некоем «артистическом» (эстетическом) индивидуализме (ЛосЕв 1982).

Индивидуализм панночки - также в ее «необычности», в желании самоутверждения наперекор воле других (в частности, Хомы), наконец в самой ее «страстности» и «аффективности», превышающих человеческие масштабы в целом.

Идея магизма в эпоху Возрождения понималась и развивалась в русле идеи покорения природы, «приручения» мира, всемерного распространения человеком владычества над внешней действительностью, превышения человеческой личностью рамок своей идентичности (т. е. «соревнования» с Божеством).

Один из завершителей натурфилософии английского Ренессанса (и Ренессанса вообще), наметивший выход к последующей эпохе Нового времени, философ (и один из претендентов на «авторство» произведений Шекспира ср. ГЕРмАН 2008) Ф. Бэкон пророчил дальнейший ход истории через потерю «идиллии» и установление «власти над природой» (Бэкон 1972: 222).

В самом деле, та «идиллия», которую вроде бы обнаруживает в себе поместье панночки, заменяется в итоге столкновением Хомы с непривычными для него реалиями, с неким «иным» порядком мира (Шульц 2017). Это столкновение гибельно для обеих сторон: и для Хомы, и для панночки. В церкви умершая панночка выступает уже больше в «страдательной» функции: мстит Хоме то ли за «неудавшиеся узы» (ср. образ Медеи), то ли за свой уход из жизни.

Панночка пытается установить контакт с бурсаком и уже будучи мертвой, что дополняет метасюжет Медеи. Когда Хома «приписывает» панночке бесовское, то он мыслит «по-старому» («по-средневековому»): он «верит» в существование нечистой силы, наделяя панночку и ее покровителей тем смыслом, от актуализации которого в итоге и погибает. Поэтому когда Р. В. Гуляев пишет о том, что изображенное Гоголем общество подвергает Хому всяческому остракизму, сознательно зная о потенциальной гибельности бдений героя над гробом умершей, но все же толкая Хому на этот шаг (Гуляев 2015), то исследователь не вполне точен.

Хома уже сам изначально выбирает «ведьмовской код» трактовки фигуры панночки: «Философ хотел оттолкнуть ее руками, но к удивлению заметил, что руки его не могут приподняться, ноги не двигались, и он с ужасом увидел, что даже голос не звучал из уст его: слова без звука шевелились на 
губах. Он слышал только, как билось его сердце; он видел, как старуха подошла к нему, сложила ему руки, нагнула ему голову, вскочила с быстротою кошки к нему на спину, ударила его метлой по боку, и он, подпрыгивая, как верховой конь, понес ее на плечах своих. Все это случилось так быстро, что философ едва мог опомниться и схватил обеими руками себя за колени, желая удержать ноги; но они, к величайшему изумлению его, подымались против воли и производили скачки быстрее черкесского бегуна. Когда уже минули они хутор и перед ними открылась ровная лощина, а в стороне потянулся черный, как уголь, лес, тогда только сказал он сам в себе: „эге, да это ведьма“» (Гоголь 2009: 421-422).

С другой стороны, после нанесенных панночке побоев и ее неожиданного преображения Хома оценивает ее иначе: «Перед ним лежала красавица с растрепанною роскошною косою, с длинными, как стрелы, ресницами. Бесчувственно отбросила она на обе стороны белые нагие руки и стонала, возведя кверху очи, полные слез.

Затрепетал, как древесный лист, Хома: жалость и какое-то странное волнение и робость, неведомые ему самому, овладели им...» (Гоголь 2009: 423).

В последней цитате панночка - уже не «ведьма», а молодая пленительная красавица. Подобные двоения восприятия Хомы (между одной и другой трактовками панночки) продолжатся и в церкви. Разумеется, можно сказать, что в гоголевском тексте одна трактовка Хомы не отрицает другую - и в такой оценке будет зерно истины. Вместе с тем в выбранном нами ракурсе рассмотрения «Вия» допустимо развести эти трактовки.

То, что Хома и его приятели набрели ночью на хутор панночки случайно, свидетельствует именно в пользу существования разных возможностей развития сюжета, в том числе в пользу определенной (не безусловной) свободы выбора Хомой трактовки личности панночки и всех дальнейших событий.

Для смыслозадающего ряда Возрождения восходящий к античности метасюжет о Медее включен в этическую и эстетическую трактовку вообще любви как совмещающей посюстороннее и потустороннее, имеющей космически-эстетический охват и масштаб. Эти смыслы вполне реализованы в коллизиях «Вия».

Вместе с тем для «Вия» вполне значим метасюжет о Медее в виде самодостаточного, в том числе вне потенциального соотнесения с Ренессансом.

Согласно древнегреческой мифологии, отец Медеи - сын Солнца, т. е. она имеет божественное происхождение. Любовь ее к Ясону наслана богами же, чем подчеркивается «надындивидуальный» генезис и характер аффекта (однако в трагедиях Еврипида и Сенеки этот момент практически не фиксируется). Чтобы помочь Ясону и команде аргонавтов добыть золотое руно, Медея бросает свою страну, убивает брата. Подоплека ее поступков - в желании добиться благосклонности Ясона (Ботвинник 1992).

У Еврипида сюжет о Медее «психологизирован» (в общем соответствии с известной логикой его творчества) и даже заметно «приземлен», подан 
в основном в качестве сюжета об измене мужа и мести жены (Лосев 2005: 157-158) - т. е., в главном, вне топики сверхъестественного. Кормилица в зачине еврипидовской трагедии произносит:

Удел

Медеи стал иной. Ее не любят.

И нежные глубоко страждут узы.

(ЕВРипид 1980: 61)

Здесь сразу задано сочувствие к Медее, идея чего затем проводится через монологи Хора. «Узы» названы «нежными», что облагораживает, «утончает» образ Медеи. Вместе с тем у Еврипида месть Медеи Ясону имеет подоплекой (среди прочего) нежелание осуждения со стороны других, «позора» (Еврипид 1980: 118; о «позоре» будет говорить и тетка покинутой невесты в гоголевской «Женитьбе»), того, чтобы другие над ней «смеялись» (ЕвРипид 1980: 118).

Характерен в последнем аспекте упомянутый нами ранее образ колдуна из «Страшной мести»: ему казалось, что над ним все смеются. Смех у Еврипида и Гоголя понят в «метафизическом» значении, не просто снижающем, но снижающем онтологически.

Еврипидовский Ясон, упрекая Медею после ее мести в «безбожии» (см. Еврипид 1980: 117), в том, что та после всего «еще на солнце и на землю» «решается глядеть...» (ЕвРипид 1980: 117), вспоминает ее прежние преступления в Колхиде, называя ее «демоном», «которым боги» в него «ударили» (Еврипид 1980: 117-118). Тем самым Медея из волшебницы превращается в колдунью (в героине подчеркивается только негатив); кроме того, Ясон акцентирует косвенный запрет на взгляд («решаешься глядеть») - все это посвоему предвосхищает мотивы «Вия».

Исследовательское мнение о якобы выводе Еврипида: «страсть часто берет верх над долгом, разрушая человеческую личность» (ЛосЕв 2005: 158) нуждается в уточнении. Констатирует ли Еврипид «разрушение личности» Медеи? Драматург показывает логику ее эволюции в виде закономерной, оправданной изнутри и извне. Еврипидовская Медея лишь утверждает себя, свое своеволие в своих страстях так и в финале. На ее фоне Ясон способен предстать «эгоистом и негодяем», как считает большинство исследователей Еврипида (Дилите 2003: 123); скорее таким он изображен и в кинотрагедии П. П. Пазолини (см. Шульц 2005) - хотя Пазолини показывает, в качестве аргумента оправдания Ясона извне, крушение его политических планов в результате действий нечистоплотных правителей. Тогда попытка нового брака Ясона вызвана его желанием политической власти, в ущерб личным договоренностям с Медеей.

Подобно Медее, гоголевская панночка «своевольна», утверждая себя в своей «страсти» к Хоме, желая заполучить его в свои руки если не живого (что не удалось), то хотя бы мертвого (финал повести истолковывается и таким путем). 
Если у Еврипида Медея в итоге скрывается на колеснице в другой древнегреческий город, то у Сенеки героиня на колеснице уносится в «эфир беспредельный»»), т. е. вообще во внеземной космос - расценивая последний во всей его «беспредельности» в виде пристанища:

\section{[Ясон:]}

Лети среди эфира беспредельного:

Ты всем докажешь, что и в небе нет богов.

(Cенека 1983: 34)

И Еврипид, и Сенека дают право высказать и мотивировать свою позицию каждой стороне, оба автора учитывают различные точки зрения на изображаемые перипетии. Вместе с тем трагедия Сенеки предельно философизирована, мотивировки поведения героев здесь гораздо сложнее, многосмысленнее, чем у Еврипида. Сенека через реализацию конкретного сюжета предлагает глубоко метафизические концепции человека, богов, устройства мироздания и т. п.

Эту «философизацию» абсолютно неправомерно относить к фактам якобы «прямолинейности» и «схематичности» (Лосев 2005: 440): она предельно нюансирует построение образного мира Сенеки и его художественный смысл, в связи с чем фиксировали апелляцию Сенеки к интеллекту (BRANDT 1986: 331), а не к эмоциям. Точнее, однако, вывод Д. Дилите, констатирующей, что Сенека стремится воздействовать «и на разум, и на душу» (ДилитЕ 2003: 398) читателя /зрителя.

Медея у Сенеки борется с самим мироустройством, что вступает в противоречие со стоическими взглядами автора: согласно философии Сенеки, «у мудрости два источника: соответствие мировому порядку... и соответствие своей собственной природе» (ГРимАль 2003: 272). Тем самым налицо осуждение Сенекой (в отличие от Еврипида) своей героини:

\section{[Xop:]}

...Торный выбрав путь, не заплатишь много,

Там иди, где шли до тебя другие,

Не дерзай вовек нарушать священный

Мира порядок.

(СЕНекA 1983: 23)

Если это и осуждение, то только интеллектуальное, но не эмоциональное. Сенека выводит «философскую позицию» Медеи как самоценную, проходящую через экзистенциальное испытание. Далее в монологе Кормилицы идея бунта Медеи против богов развивается и уточняется, здесь Медея уже прямо предстает злой и злобной колдуньей:

Я видела и раньше, как богам грозит

Медея и колеблет небо в ярости, -

Но большее сегодня замышляется.

(СеНЕКА 1983: 24-25) 
Дальнейшие образы, возникающие в речи Кормилицы у Сенеки, напоминают об образах будущих покровителях ведьмы из «Вия»: «Магические действия Медеи Сенека излагает очень подробно: он описывает волшебные заклинания, всевозможные ядовитые растения, змей, яд которых Медея смешивает. От яда сгорает весь дом, и это даже угрожает городу. У Еврипида нет такого изображения магических действий, от яда погибают невеста и ее отец» (Лосев 2005: 440). Угроза пожаром целому городу расширяет масштаб коварств Медеи и вместе с тем ее внутренний масштаб в качестве мстительницы.

Процитируем слова Кормилицы о подготовке Медеи к отмщению.

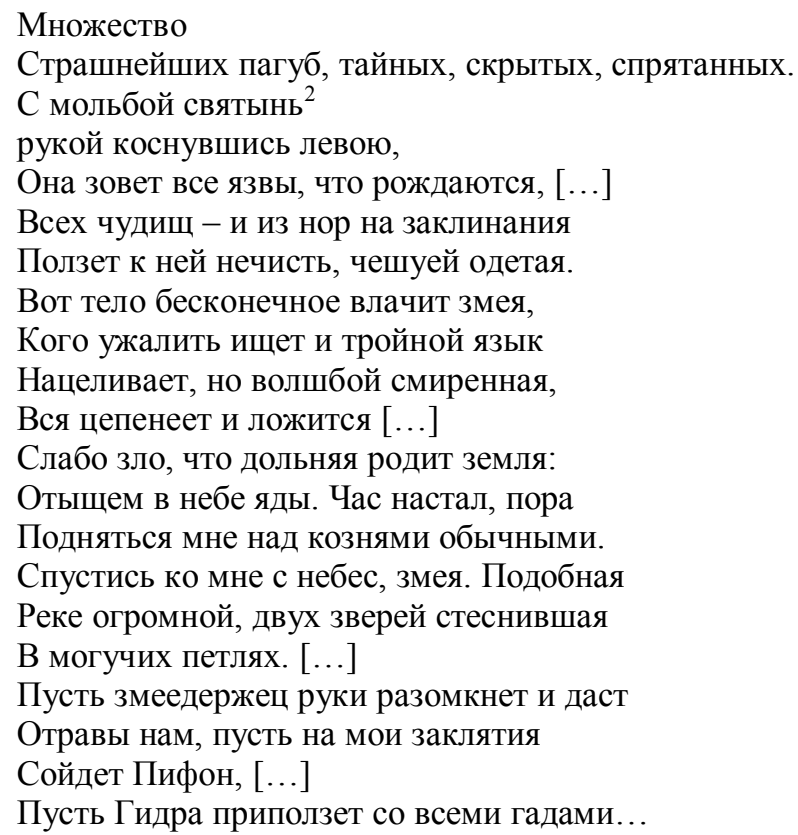

(CЕHEKA 1983: 25)

Медея у Сенеки апеллирует не только к подземным, хтоническим силам, но и к силам «небесным»- олимпийским, отсюда, в частности, упоминание «змеедержца» Аполлона. Во время полета с ведьмой - благодаря ей - гоголевский Хома зрит и небесное, и земное, и даже подземное, а во время нахождения мертвой ведьмы в церкви на помощь ей приходят силы хтонические - все это в перекличке с тем, что описывает Кормилица Медеи в трагедии Сенеки.

Наконец у Сенеки предвосхищен мотив страшного взгляда, актуальный для сюжетной ситуации «Вия» - в ней играет роль взгляд не только «начальника гномов» (Гоголь 2009: 414), но и панночки:

${ }^{2} \mathrm{Cp}$. церковный хронотоп бдений Хомы Брута - С. Ш. 
И очи

Царю грозят.

(СЕНЕКА 1983: 29)

Трагедия Сенеки обнаруживает больше точек соприкосновения с «Вием» на уровне сознания Хомы, чем еврипидовская. Ведь Хома рассматривает панночку в качестве ведьмы, что коррелирует с аттестациями Сенекой его Медеи. Потенциальные гоголевские аллюзии на Сенеку нужно соотнести с общим вниманием Гоголя к стоикам (см. Чернов 2003, REID 2004).

С другой стороны, возможная альтернативная оценка панночки как «ренессансной» личности обращает уже больше к Еврипиду, увидевшему в Медее лишь самоценные аффекты ревности, трагические страсти покинутой женщины. Еврипидовское толкование ближе к «личному мифу» А. А. Ахматовой (ср. также специальные работы, сближающие классика XIX в. с классиками века ХХ - ЛиХАчев 1987, ХомЕнко 1999).

Хорошо известен факт ахматовской автомифологии (автомифологий) (ср. ПАк 2015). ${ }^{3}$ Она строилась Ахматовой, с одной стороны, в качестве отклика на «молву» других о ней, а с другой - в соотнесении с известными мифопоэтическими или легендарными образами.

Мифопоэтическую трактовку образа Ахматовой словно в русле сюжетной ситуации «Вия» и, вместе с тем, метасюжета о Медее 4 дал ранний Н. С. Гумилев, в стихотворении которого прямо упомянут Киев (как и в повести Гоголя):

Из логова змиева,

Из города Киева,

Я взял не жену, а колдунью.

А думал - забавницу,

Гадал - своенравницу,

Веселую птицу-певунью [...]

А выйдет луна-затомится,

И смотрит, и стонет,

Как будто хоронит

Кого-то...

(ГуМИЛЕВ 1991: 131)

И Гумилев предлагает «колдунье» отказаться от «магии»:

Снеси-ка истому ты

В днепровские омуты,

На грешную Лысую гору. [...]

Мне жалко ее, виноватую,

${ }^{3} \mathrm{Cp}$. также мифологизацию фигуры Ахматовой как «последнего поэта» (см. Тименчик 2014-2015). 2015).

${ }^{4}$ Имя Ахматовой отсутствует, к сожалению, в работе Т. А. Шарыпиной (см. ШАРыпинА 
Как птицу подбитую,

Березу подрытую

Над очастью, Богом заклятою

(ГумИЛЕВ 1991: 131)

Мотивы «Вия» соединяются у Гумилева с прямыми мотивами мифологии и фольклора, но отчасти и «Медей» Еврипида и Сенеки (ср. образы змеи, колдуньи, «своенравницы», «очасти, Богом заклятой», мотив «виноватости» «колдуньи» и др.)

По замечанию Е. Ю. Куликовой, у Н. С. Гумилева путь, совершаемый им вместе с возлюбленной, нередко «пролегает не столько во внешнем мире, сколько в сфере чувств и внутренней жизни» (КуликовА 2015: 86). ${ }^{5}$ В случае же процитированного стихотворения путь внешний и путь внутренний полностью совпадают: имманентная экзотика и мистика киевского локуса («логова змиева») уже сами собой предопределяют непростой путь семейной пары...

Своеобразным ответом Гумилеву со стороны Ахматовой стали ее строки, хотя они созданы уже после развода с ним:

Тебе покорной? Ты сошел с ума.

Покорна я одной господней воле

(1921; АхматовА 1990: 148)

В лирике Ахматовой имеется прямая отсылка к «Вию»:

Я знаю, с места не сдвинуться

Под тяжестью Виевых век.

О, если бы вдруг откинуться

В какой-то семнадцатый век.

(1937; Ахматова 1990: 256)

Здесь, на фоне изображения личных и социальных катаклизмов (напомним дату создания: 1937), образ Вия осмыслен социально-негативно, как нечто «тяжелое», заставляющее окаменеть в «социософском» аспекте («с места не сдвинуться») и искать пристанища в другой исторической эпохе русской жизни («какой-то семнадцатый век»). Вместе с тем ахматовское «откинуться», к тому же в «какой-то век» не исключает поиска автопараллелей в других веках и культурах, например, в метасюжете о Медее. Еврипидовскую «Медею» мы цитировали в переводе И. Ф. Анненского, названного Ахматовой своим «учителем» (АхмАтовА 1990: 249). Анненский создал, по точному выражению Ф. Ф. Зелинского, «русского Еврипида» (ЗЕлинский 1995: 373) и в значении целостного корпуса переводов, и в значении «привития» творчества древнегреческого драматурга к древу русской культуры.

${ }^{5}$ Ср. путь Медеи из Колхиды и «путь» взаимоотношений Ахматовой и Гумилева (во всех смыслах). 
Хотя поздний ахматовский цикл «Шиповник цветет» обращен в аспекте мифопоэтики прежде всего к истории Дидоны и Энея, в нем наличествуют также косвенные переклички с образом Медеи, в том числе как он преломлен в «Вие»:

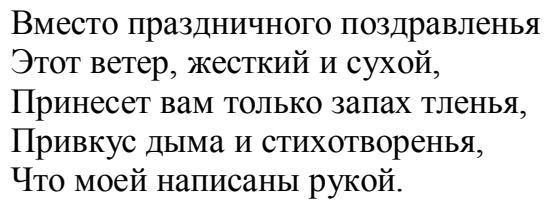

Вместо праздничного поздравленья

Этот ветер, жесткий и сухой, Принесет вам только запах тленья, Привкус дыма и стихотворенья, Что моей написаны рукой.

(1959; Ахматова 1990: 268)

«Запах тленья», «привкус дыма» - это напоминает о реалиях мести Медеи. Те же реалии в трансформированном, метафорическом виде - в описании сожжения поэтом своей поэтической «тетради», понятой как производное от своей личности, нечто родное, кровное:

Уже красуется на книжной полке

Твоя благополучная сестра,

А над тобою звездных стай осколки

И под тобою угольки костра.

(1961; Ахматова 1990: 269)

Обращение «твоя... сестра» прямо оценивает сожженную тетрадь в качестве собственного «ребенка». Дальнейшие строки косвенно напоминают о мольбах уничтоженных детей Медеи:

Как ты молила, как ты жить хотела,

Как ты боялась едкого огня!

(1961; Ахматова 1990: 269)

В конечном счете «сожженная тетрадь - символ мистического жертвоприношения своего искусства, но ради собственного искусства же в целом, ради искусства вообще.

O «вызове Судьбе» - вызове, подобном совершаемому Медеей у Сенеки, Ахматова говорит в цикле далее:

Ты отдал мне не тот подарок,

Который издалека вез.

Казался он пустой забавой

В тот вечер огненный тебе.

А он был мировою славой

И грозным вызовом Судьбе.

(1956; Ахматова 1990: 273)

Рассуждая далее о «невстрече» с возлюбленным, Ахматова оценивает ее в категориях огня, также напоминающих о реалиях мести Медеи: 
Медея - один из разных прообразов, «масок», архетипов ахматовского «автора-героя». Хотя Ахматова в своей лирике практически никогда не поднимает, например, тему мести, но она нередко фиксирует эпизоды своей оставленности, вообще трагедийной кризисности в любовных взаимоотношениях. Встречается у нее и проклятие:

Будь же проклят.

(Aхматова 1990: 165)

Трагедийность расширяется у Ахматовой до выхода за пределы личного опыта, в сферу большой исторической жизни, в ключе античности охватывающей даже космос (например, в лирических циклах «Шиповник цветет» и «Северные элегии»).

Очень непростое отношение Ахматовой к своему сыну Льву Гумилеву, с одной стороны, допустимо передать в терминах метафорического «отмщения» его отцу (как у Медеи): когда «обиды» на мужа переносятся на сына или когда сын условно занимает место отца. Ахматова всегда хранила очень добрую, высокую память о первом муже, но вместе с тем и определенные претензии. С другой стороны, в ахматовском восприятии сына видятся черты некоего возвышенного «жертвоприношения» - «Молоху», «Вию» и т. д. Жертва сделана ради творчества, религиозно понятого. В ахматовском цикле «Реквием»- прямое сопоставление сына с Христом, принесенным в жертву за весь мир.

Прообраз Медеи акцентирует в поэтической личности Ахматовой черты противоборства с судьбой, вызова, бросаемого со стороны «морской царевны» (это наименование Ахматова применяет к себе в цикле «Северные элегии»), почти божественной (ср. происхождение Медеи от сына Солнца), но вместе с тем и столь посюсторонней в своих аффектах.

\section{Литература}

Ахматова $1990=$ Ахматова А. А. Сочинения в 2 томах. Т. 1 . Москва, 1990.

БЕлый 1996 = Белый Андрей: Мастерство Гоголя. Москва, 1996.

Ботвинник 1992 = Ботвинник М. Н. Медея. В кн.: Мифы народов мира. Энциклопедия в 2 томах. Т. 2. Москва, 1992. 130-131.

Бэкон 1972 = Бэкон Ф. Новый органон. В кн.: Бэкон Ф. Сочинения в 2 mомах. Т. 2. Москва, 1972. 3-222.

ГЕРМАН $2008=$ ГЕРМАН В. Портрет Шекспира, или Личное дело Фрэнсиса Бэкона. Москва, 2008.

Гоголь 2009 = Гоголь Н. В. Полное собрание сочинений и писем в 17 томах. Т. 2. Москва-Киев, 2009.

ГримАль 2003 = ГРимАЛь П. Сенека, или Совесть империи. Москва, 2003. 
ГуляЕв $2015=$ ГуляЕв Р. В. Философ перед лицом бессловесного ужаса («Вий» Н. В. Гоголя). Вопросы философии 2015/9: 102-113.

ГумиЛЕв 1991 = ГумиЛЕв Н. С. Сочинения в 3 mомах. Т. 1. Москва, 1991.

Дилите 2003 = ДилитЕ Д. Античная литература. Москва, 2003.

Еврипид 1980 = Еврипид: Трагедии. Т. 1. Москва, 1980.

ЗЕлинский 1995 = ЗЕлинский Ф. Ф. Памяти И. Ф. Анненского. В кн.: ЗЕлинский Ф. Ф. Из жизни идей. Т. 2. Москва, 1995. 364-378.

КуликовА 2015 = КуликовА Е. Ю. «Дальние небеса» Н. Гумилева. Поэзия, проза, переводы. Новосибирск, 2015.

ЛиХАЧЕВ $1987=$ ЛиХАЧЕВ Д. С. Ахматова и Гоголь. В кн.: ЛиХАчЕВ Д. С. Избранные работы в 3 томах. Т. 3. Ленинград, 1987. 298-302.

Лосев 1982 = Лосев А. Ф. Эстетика Возрождения. Москва, 1982.

Лосев 2005 = Лосев А. Ф. Античная литература. Москва, 2005.

ПАК 2015 = ПАК Сун Юн: Жизнетворческие маски Анны Ахматовой (к стратегиям автомифологизации). Русская литература 2015/3: 215-226.

РозАнов 1995 = РозАнов В. В. Гоголь и Петрарка. В кн.: РозАнов В. В. Собрание сочинений. О писательстве и писателях. Москва, 1995. 658-659.

СЕНЕКА 1983 = СЕНЕКА: Трагедии. Москва, 1983.

СуГАЙ 2011 = СуГАЙ Л. А. Гоголь и символисты. Banská Bystrica, 2011.

Тименчик 2014-2015 = Тименчик Р. Последний поэт. Анна Ахматова в 1960-е годы. Т. 1-2. Москва, 2014-2015.

ХомЕнко 1999 = ХОмЕнко Л. И. Петербург Гоголя в «Египетской марке» Мандельштама и «Поэме без героя» Ахматовой. В кн.: Література та культура Полісся. Вып. 12. Ніжин, 1999. 180-188.

ЧЕРнов 2003 = ЧЕРнов Д. А. Заметки о духовно-назидательных сочинениях Н. В. Гоголя. В кн.: Гоголевский сборник. Санкт-Петербург-Самара, 2003. 234-244.

ШАРЫПИНА 2015 = ШАРЫПинА Т. А. Медея ХХ века. Русские версии в европейском контексте. http://culture-code.ru/wp-content/uploads/2015/12/Шарыпина-Т.A.-Медея-XX-века.-Русские-версии-в-европейском-контексте.pdf.

Шульц 1994 = Шульц С. А. Гоголь. Личность и художественный мир. Москва, 1994.

Шульц 2005 = Шульц С. А. Еврипид - Сенека - Пазолини. Интерпретация античного мифа в кинотрагедии П. П. Пазолини «Медея». Филологический вестник Ростовского государственного университета. № 1. Ростов, 2005. 20-22.

Шульц 2017 = Шульц С. А. Трансформация инфернального в идиллическом. ГогольЛ. Толстой - Бунин. Проблемы исторической поэтики. Т. 15. № 3. Петрозаводск, 2017. 127-147. http://poetica.pro/journal/content_list.php?id=74621.

BRANDT 1986 = BRANDT J. Argumentative Struktur in Senecas Tragödien. HildesheimNew York, 1986.

ReID 2004 = Reid R. Gogol. A Stoic Approach. Essays in Poetics. Vol. 29. № 9. Keele, 2004. 145-160. 